
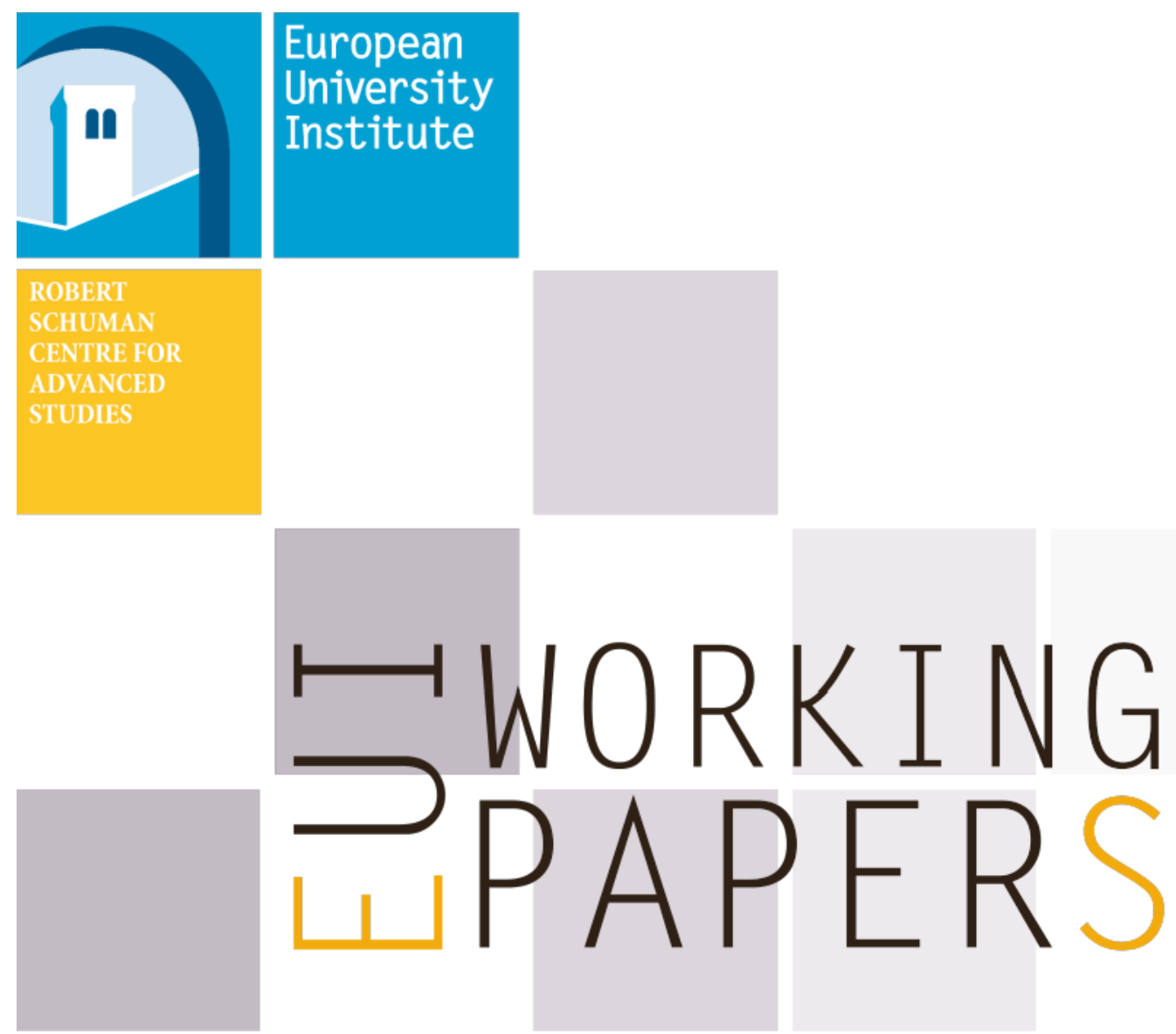

RSCAS 2019/87

Robert Schuman Centre for Advanced Studies Global Governance Programme-375

The Gravity of Intermediate Goods

Paola Conconi, Glenn Magerman, Afrola Plaku 

European University Institute

Robert Schuman Centre for Advanced Studies

Global Governance Programme

\section{The Gravity of Intermediate Goods}

Paola Conconi, Glenn Magerman, Afrola Plaku

EUI Working Paper RSCAS 2019/87 
This text may be downloaded only for personal research purposes. Additional reproduction for other purposes, whether in hard copies or electronically, requires the consent of the author(s), editor(s). If cited or quoted, reference should be made to the full name of the author(s), editor(s), the title, the working paper, or other series, the year and the publisher.

ISSN 1028-3625

(C) Paola Conconi, Glenn Magerman, Afrola Plaku, 2019

Printed in Italy, October 2019

European University Institute

Badia Fiesolana

I - 50014 San Domenico di Fiesole (FI)

Italy

www.eui.eu/RSCAS/Publications/

www.eui.eu

cadmus.eui.eu 


\section{Robert Schuman Centre for Advanced Studies}

The Robert Schuman Centre for Advanced Studies, created in 1992 and currently directed by Professor Brigid Laffan, aims to develop inter-disciplinary and comparative research on the major issues facing the process of European integration, European societies and Europe's place in $21^{\text {st }}$ century global politics.

The Centre is home to a large post-doctoral programme and hosts major research programmes, projects and data sets, in addition to a range of working groups and ad hoc initiatives. The research agenda is organised around a set of core themes and is continuously evolving, reflecting the changing agenda of European integration, the expanding membership of the European Union, developments in Europe's neighbourhood and the wider world.

For more information: http://eui.eu/rscas

The EUI and the RSCAS are not responsible for the opinion expressed by the author(s).

\section{The Global Governance Programme}

The Global Governance Programme is one of the flagship programmes of the Robert Schuman Centre. It is a community of outstanding professors and scholars, that produces high quality research and engages with the world of practice through policy dialogue. Established and early-career scholars work on issues of global governance within and beyond academia, focusing on four broad and interdisciplinary areas: Global Economics, Europe in the World, Cultural Pluralism and Global Citizenship.

The Programme also aims to contribute to the fostering of present and future generations of policy and decision makers through its executive training programme: the Academy of Global Governance, where theory and 'real world' experience meet and where leading academics, top-level officials, heads of international organisations and senior executives discuss on topical issues relating to global governance.

For more information: http://globalgovernanceprogramme.eui.eu

The European University Institute and the Robert Schuman Centre are not responsible for the opinions expressed by the author(s). 



\begin{abstract}
One of the puzzles of the gravity literature is the persistent effect of distance on trade flows, despite the dramatic fall in trade costs during the last few decades (Disdier and Head, 2008). A possible reason for the Idistance puzzle" is that trade in intermediate goods, which has risen dramatically during this period due to the emergence of global value chains, may be more sensitive to distance than trade in final goods. Using a dataset of bilateral import flows covering 5000 products and more than 200 countries over the 1998-2011 period, we show that intermediate goods are indeed more sensitive to distance than final goods, with differentiated inputs exhibiting the highest distance elasticity. The results are robust to including different sets of controls, and using different samples and econometric methodologies. They suggest that sourcing inputs from nearby countries helps final good producers to better coordinate with their suppliers, monitor their production, and insure the timely delivery of inputs that need to be tailored to their needs.
\end{abstract}

\title{
Keywords
}

Gravity, distance, intermediate goods, final goods, product differentiation.

JEL classification: F14, F23. 



\section{Introduction $^{1}$}

During the last three decades, advances in information and communication technology and falling trade barriers have made it easier for firms to source key inputs from foreign suppliers and to fragment their production processes across countries. Research and development, design, production of parts, assembly, marketing and branding, previously performed in close proximity and within the same firm, are increasingly fragmented across the globe and across firms. As a result of the emergence of global value chains (GVCs), trade in intermediate inputs now accounts for as much as two-thirds of international trade (Johnson and Noguera, 2012). These trends have led some to announce "the death of distance" (Cairncross, 1997) and argue that "certainly it is an exaggeration to claim that moving goods is free, but it is becoming an increasingly apt assumption" (Glaeser and Kohlhase, 2004).

At the same time, the gravity literature of international trade has emphasized the persistent effect of distance on bilateral trade. In an influential meta-analysis study, Disdier and Head (2008) investigate the trends in the variation of 1467 distance estimates from 103 papers and provide systematic evidence that "the estimated negative impact of distance on trade rose around the middle of the century and has remained persistently high since then." They find distance effects to be persistent in two senses: they hold up in a very wide range of samples and methodologies, and they are not declining in more recent data.

In this paper, we argue that the emergence of GVCs can help to explain the "distance puzzle." While fragmenting production across firms and countries has become easier, contractual frictions remain a significant obstacle to the globalization of value chains. On top of the inherent difficulties associated with designing richly contingent contracts, international transactions suffer from a disproportionately low level of enforcement of contract clauses and legal remedies (Antràs, 2016). Contracting frictions are particularly severe when they involve relationship-specific inputs, i.e. differentiated/non-standardized inputs that must be tailored to the need of final good producers (Nunn, 2007). Sourcing these inputs from nearby countries can allow producers to better coordinate with suppliers and to monitor their production. Using more distant suppliers can give rise to problems and delays in the production of key inputs, which can disrupt the entire supply chain.

In light of these contracting frictions, it is then not surprising that GVCs are actually regional in nature. As pointed out by Baldwin (2013), trade in intermediate goods is concen-

\footnotetext{
${ }^{1}$ We are grateful for their comments and suggestions to Peter Egger, Mathieu Parenti, André Sapir, and seminar and conference participants at ECARES, EUI, and Warsaw School of Economics. Paola Conconi gratefully acknowledges financial support from the FNRS and the ERC (project 834253 - TRASC). Correspondence should be addressed to Paola Conconi, pconconi@ulb.ac.be.
} 
trated within "Factory North America," "Factory Europe," and "Factory Asia." This can partly be attributed to the role of regional trade agreements, which can distort input trade towards suppliers in partner countries (e.g. Conconi et al., 2018). In this paper, we argue that the regional nature of supply chains can also be explained by the higher sensitivity to distance of intermediate goods, and in particular of differentiated inputs.

A few studies have already noted that intermediate goods are more sensitive to distance than final goods (Miroudot et al., 2009; Bergstrand and Egger, 2010; Baldwin and Taglioni, 2011). In this paper, we provide systematic evidence for this difference and explore the mechanisms behind it.

We construct a product-level panel dataset, covering more than 5000 products and more than 200 countries and territories over the 1998-2011 period. We employ the BEC classification to distinguish HS6 products into final and intermediate and the classification by Rauch (1999) to distinguish between homogeneous and differentiated goods.

Using this dataset, we first show that intermediate goods are indeed more sensitive to distance. This result is robust to including different sets of fixed effects and controls, exploiting cross-sectional and time series variation in trade flows, and using alternative econometric methodologies.

One possible explanation for this result is that some inputs are raw materials, which can be less easily traded across long distances due to their bulky nature (Miroudot et al., 2009). We dismiss this mechanism, showing that the higher sensitivity to distance of intermediate goods is robust to excluding raw materials. In fact, the difference in the distance elasticity between final and intermediate goods is even larger when excluding raw materials.

Finally, we show that differentiated inputs are the most sensitive to distance. This is in line with the idea that final good producers tend to source relationship-specific inputs, which need to be tailored to their specific needs, from nearby suppliers. Sourcing differentiated inputs from suppliers in more distant countries could give rise to various problems/delays, disrupting their whole supply chain.

\section{Related Literature}

Our analysis is related to two main streams of studies: the literature on global sourcing and the organization of supply chains, and the literature on the distance puzzle.

First, the emergence of GVCs has motivated a stream of studies on firms' sourcing decisions. A growing body of literature studies the causes and consequences of increasing 
production fragmentation across countries and the global sourcing of inputs. Several studies emphasize the productivity-enhancing effects of input trade, showing that it allows firms to reduce production costs by accessing novel, cheaper, or higher quality foreign inputs (e.g. Amiti and Konings, 2007; Goldberg et al., 2010). Other studies examine the determinants of firm boundary choices along value chains (Antràs and Chor, 2013; Alfaro et al., 2019). Another stream of the literature emphasizes selection effects. Bernard et al. (2007) shows that US importers are on average more than twice as large than non-importers. Antràs et al. (2017) develop a theoretical model that can rationalize this heterogeneity. They examine the margins of global sourcing in a multi-country environment. In their model, a firm can add one country to the set of countries from which it is able to import, but this requires incurring a market-specific fixed cost. As a result, relatively unproductive firms opt out of importing from countries that are not particularly attractive sources of inputs. The global sourcing strategy of a firm is to determine the set of countries from which to source inputs, based on cross-country differences in technology, trade costs, and wages. A related study by Blaum et al. (2018) develops a multi-country quantitative model to study the effect of imported inputs on firm-level and aggregate productivity.

Second, many studies have provided econometric evidence suggesting that in the context of the gravity model the elasticity of bilateral trade with respect to distance has increased over time. Leamer and Levinsohn (1995) were the first to draw attention to this trend, concluding that, contrary to popular notions of globalization, the world is not "getting smaller." They argue, in line with the gravity approach, that the driving force behind globalization is not lower distance-barriers, but increased dispersion of economic mass around the globe. Combes et al. (2008) estimate distance coefficients year by year, using fixed effects for exporters and importers. They find a pattern of rising coefficients since the 1950s. Berthelon and Freund (2004) study industry-level trade finds that 75 percent of industries do not exhibit significant changes in the distance effect. The significant changes are almost all in the direction of a larger distance effect over the 1985-2000 period. Many other studies on the "distance puzzle" are reviewed in the meta-analysis study by Disdier and Head (2008). Our paper exploits product-level data on bilateral trade flows to show that inputs are more sensitive to distance than final goods, particularly when they are differentiated and thus need to be tailored to the needs of final good producers. ${ }^{2}$

\footnotetext{
${ }^{2}$ Our analysis builds on earlier studies that have estimated gravity regressions at the product or sectoral level (e.g. Anderson and Yotov, 2010; Imbs and Mejean, 2017).
} 


\section{Data}

We perform our analysis at the product level, using disaggregated data on bilateral trade flows from the United Nations's Comtrade dataset. The trade data is defined at the 6-digit level of the Harmonized System (HS) classification, which covers more than 5000 products. Our sample covers 212 countries and territories over the period 1998-2011.

Given our interest in GVCs and sourcing decisions, we focus on imports rather than exports. The dependent variable in our regressions is the log of Imports $_{k i j t}$, the value of imports of HS6 product $k$ of country $i$ from country $j$ in year $t$ (in current US dollars).

To distinguish between final and intermediate goods, we use the United Nations's Broad Economic Categories (BEC) classification, in line with previous studies (e.g. Bergstrand and Egger 2010; Alfaro et al., 2019). The BEC is a subjective expert judgment classification that distinguishes products according to their end-use. The original data is in based on the SITC classification, but the UN Trade Statistics Division provides a table allowing to convert it at the HS6 level. The BEC distinguishes between intermediate, capital, or consumption goods. As an example, roasted, decaffeinated coffee (HS 090121) is classified as a consumption good, while its non-roasted version (HS 090112) is classified as an intermediate. The variable Intermediate $_{k}$ is a thus dummy equal to 1 if product $k$ is classified as intermediate according to the BEC classification and zeros otherwise. ${ }^{3}$

To distinguish between homogeneous and differentiated goods, we rely on the well-known classification by Rauch (1999). This is based on the SITC rev. 2 classification, so we employ the UN Concordance Tables to convert the data at the HS-6 digit level. Rauch classifies products in three different categories: homogeneous goods, which are traded in organized exchanges; goods that are are not traded in organized exchanges, but for which a published reference price can be found; and differentiated goods, which do not fall in neither of the two previous categories. We use the conservative version of the Rauch classification. The variable Differentiated $k$ is a dummy equal to 1 if good $k$ is "branded" goods, which does not fall in the two homogeneous goods categories (traded in organized exchanges and reference priced).

In some specifications, we exclude raw materials. Conversions from HS-6 digits products into raw and non-raw materials can be found in the WITS Classification tables. ${ }^{4}$

Finally, in some regressions we include dyadic variables taken from the CEPII Gravity

\footnotetext{
${ }^{3}$ Final goods thus comprise both capital and consumption goods. We drop from our analysis those goods that are considered "mixed' in the BEC classification.

${ }^{4}$ https://wits.worldbank.org/referencedata.html
} 
Dataset. These include the following: Distance ${ }_{i j}$ is the Distance is the bilateral distances (in kilometers, population weighted) between the capitals of countries $i$ and $j$; Contiguous $i j$ is a dummy indicating whether $i$ and $j$ share a common border; Common Language $_{i j}$ is a dummy equal to 1 if the two countries share a common language; Colony $y_{i j}$ is a dummy variable indicating whether the two countries have a colonial link; $R T A_{i j t}$ is a dummy variable equal to 1 if $i$ and $j$ are members of a regional trade agreement during in year $t$.

Descriptive statistics of the main variables used in our empirical analysis are reported in Table A 1 in the Appendix.

\section{Empirical Methodology and Results}

The empirical analysis is divided in three parts. First, we systematically examine whether intermediate goods are more sensitive to distance than final goods, as suggested by some previous studies.

In our benchmark regressions, we address this question exploiting only cross-sectoral variation in bilateral trade flows. For each year in our panel, we estimate the following regression:

$$
\begin{aligned}
\log \left(\text { Imports }_{i j k}\right)= & \alpha+\beta_{1} \text { Intermediate }_{k} \times \log \left(\text { Distance }_{i j}\right)+\beta_{2} \text { Intermediate }_{k} \\
& \beta_{3} \log \left(\text { Distance }_{i j}\right)+\beta_{4} \mathbf{X}_{i j}+\delta_{i}+\delta_{j}+\delta_{s}+\epsilon_{i j k},
\end{aligned}
$$

where Imports $_{k i j}$ is the value of imports of HS6 product $k$ of country $i$ from country $j, \mathbf{X}_{i j}$ is a vector of bilateral variables (e.g. common language, colonial relationship, membership in trade agreements), $\delta_{i}$ and $\delta_{j}$ denote fixed effects at the importer and exporter level, and the $\delta_{s}$ are fixed effects identifying the broad sector (at the HS2 level) to which product $k$ belongs. If intermediate goods are indeed more sensitive to distance than final goods (the omitted category), the coefficient $\beta_{1}$ should be negative and significant.

In the most demanding specifications, we include country-pair fixed effects $\delta_{i j}$ in (1) to account for the role of all bilateral determinants of trade flows. In these specifications, the variables Distance $_{i j}$ and $\mathbf{X}_{i j}$ are absorbed by the fixed effects.

Second, we re-estimate (1) excluding raw materials. This allows us to rule out one of the possible mechanisms for the higher sensitivity to distance of intermediate goods suggested by previous studies.

Third, we examine the role of product differentiation. If the mechanism behind the higher sensitivity to distance of intermediate goods is the complexity of global supply chains and 
the difficulty of sourcing inputs from suppliers located in far away countries, we would expect differentiated intermediate goods to be the most sensitive to distance. These are inputs that need to be tailored to the needs of final good producers, for which contracting frictions are more severe (Nunn, 2007). To verify this, we estimate

$$
\begin{aligned}
\log _{\left(\text {Import }_{i j k}\right)=} & \alpha+\beta_{1} \text { Intermediate Differentiated }_{k} \times \log \left(\text { Distance }_{i j}\right) \\
& +\beta_{2} \text { Final Differentiated }_{k} \times \log _{\left(\text {Distance }_{i j}\right)} \\
& +\beta_{3} \text { Intermediate Homogeneous }_{k} \times \log \left(\text { Distance }_{i j}\right) \\
& +\beta_{4} \text { Intermediate Differentiated }_{k}+\beta_{5} \text { Final Differentiated }_{k} \\
& +\beta_{6} \text { Intermediate Homogeneous }_{k}+\delta_{i}+\delta_{j}+\delta_{i j}+\delta_{s}+\delta_{s}+\epsilon_{i j k},
\end{aligned}
$$

where goods classified as Final Homogeneous $k$ are the omitted category. We expect the coefficient $\beta_{1}$ to be negative and significant and to be larger in absolute terms than the coefficients $\beta_{2}$ and $\beta_{3}$.

\subsection{Benchmark Results}

Table 1 reports the results of estimating (1) for six-year intervals. In all specifications, the coefficient of the dummy Intermediate ${ }_{k}$ is positive and significant, indicating that countries in our sample period countries trade more (in terms of value of imports) in intermediate goods than final goods, in line with what has been pointed out by recent papers on global supply chains (e.g. Johnson and Noguera, 2012).

The key results is that coefficient of the interaction term Intermediate $_{k} \times \log \left(\right.$ Distance $\left._{i j}\right)$ is negative and highly significant, indicating that imports of intermediate goods are more sensitive to distance than imports of final goods. In terms of magnitude, the results of Table 1 show that the distance elasticity is by between -0.017 and 0.023 percentage points more negative for intermediate goods compared to final goods. Based on the specifications in which we omit country-country pair fixed effects (columns 1, 3, and 5), our estimates imply that the distance elasticity is between $5.84 \%$ and $7.75 \%$ higher for intermediate goods relative to final goods.

The estimates also confirm standard results in the gravity literature on the role of other bilateral determinants of trade flows: countries trade more when they share a common border or a common language, have a historical colonial relationship, and are members of regional trade agreements. 


\section{Table 1}

Sensitivity to distance, imports of intermediate vs final goods

\begin{tabular}{|c|c|c|c|c|c|c|}
\hline & (1) & $(2)$ & $(3)$ & (4) & $(5)$ & $(6)$ \\
\hline Intermediate $_{k} \times \log \left(\right.$ Distance $\left._{i j}\right)$ & $\begin{array}{c}-0.023^{* * *} \\
(0.007)\end{array}$ & $\begin{array}{c}-0.017^{*} \\
(0.007)\end{array}$ & $\begin{array}{c}-0.029 * * * \\
(0.007)\end{array}$ & $\begin{array}{c}-0.023^{* * *} \\
(0.007)\end{array}$ & $\begin{array}{c}-0.025^{* * *} \\
(0.006)\end{array}$ & $\begin{array}{c}-0.018^{* *} \\
(0.007)\end{array}$ \\
\hline Intermediate $_{k}$ & $\begin{array}{c}0.180^{* * *} \\
(0.054)\end{array}$ & $\begin{array}{l}0.134^{*} \\
(0.055)\end{array}$ & $\begin{array}{c}0.167^{* *} \\
(0.054)\end{array}$ & $\begin{array}{l}0.119^{*} \\
(0.055)\end{array}$ & $\begin{array}{c}0.193^{* * *} \\
(0.053)\end{array}$ & $\begin{array}{l}0.136^{*} \\
(0.054)\end{array}$ \\
\hline $\log \left(\right.$ Distance $\left._{i j}\right)$ & $\begin{array}{c}-0.341^{* * *} \\
(0.015)\end{array}$ & & $\begin{array}{c}-0.374^{* * *} \\
(0.015)\end{array}$ & & $\begin{array}{c}-0.428^{* * *} \\
(0.014)\end{array}$ & \\
\hline Contiguous $_{i j}$ & $\begin{array}{c}0.440^{* * *} \\
(0.050)\end{array}$ & & $\begin{array}{c}0.379 * * * \\
(0.045)\end{array}$ & & $\begin{array}{c}0.401^{* * *} \\
(0.043)\end{array}$ & \\
\hline Common Language $_{i j}$ & $\begin{array}{c}0.109 * * * \\
(0.032)\end{array}$ & & $\begin{array}{c}0.092^{* * *} \\
(0.026)\end{array}$ & & $\begin{array}{c}0.122^{* * *} \\
(0.027)\end{array}$ & \\
\hline Colony $_{i j}$ & $\begin{array}{c}0.130^{* * *} \\
(0.034)\end{array}$ & & $\begin{array}{c}0.118^{* * *} \\
(0.033)\end{array}$ & & $\begin{array}{c}0.134^{* * *} \\
(0.035)\end{array}$ & \\
\hline $\mathrm{RTA}_{i j t}$ & $\begin{array}{c}0.230^{* * *} \\
(0.032)\end{array}$ & & $\begin{array}{c}0.153^{* * *} \\
(0.028)\end{array}$ & & $\begin{array}{c}0.122^{* * *} \\
(0.023)\end{array}$ & \\
\hline Exporter FE & Yes & Yes & Yes & Yes & Yes & Yes \\
\hline Importer FE & Yes & Yes & Yes & Yes & Yes & Yes \\
\hline Country-pair FE & No & Yes & No & Yes & No & Yes \\
\hline HS2 FE & Yes & Yes & Yes & Yes & Yes & Yes \\
\hline Year & 1998 & 1998 & 2004 & 2004 & 2010 & 2010 \\
\hline $\mathrm{N}$ & $4,785,880$ & $4,783,424$ & $5,544,965$ & $5,541,660$ & $6,098,518$ & $6,095,428$ \\
\hline $\mathrm{R}^{2}$ & 0.197 & 0.231 & 0.189 & 0.222 & 0.206 & 0.240 \\
\hline
\end{tabular}

The table reports the coefficients of OLS regressions. The dependent variable is the log of Imports $_{i j k}$, the value of imports of HS6 product $k$ of country $i$ from country $j$. Standard errors in parenthesis clustered at the country-pair level. Significance levels: ${ }^{*} p<0.05,{ }^{* *} p<0.01,{ }^{* * *} p<0.001$.

In Table 2, we reproduce Table 1 excluding products classified as raw materials from our sample of HS6 goods. As mentioned before, some earlier studies point that many intermediate inputs are raw materials and that the bulky nature of these goods could explain why they are less easily traded across long distances. Raw materials represent $16 \%$ of all bilateral trade flows. The majority of HS6 products classified as raw materials are indeed intermediate goods. ${ }^{5}$

${ }^{5}$ Raw materials correspond to 575 HS6 codes in our sample. Of these, 379 are intermediate goods, $43.20 \%$ of which are homogeneous (e.g. oil, fertilizers, copper) and $22.61 \%$ are differentiated (e.g. glass containers, live animals, plants and parts, including seeds and fruits). The remaining products are final goods, some of which are homogeneous (e.g. frozen fish fillets, frozen shrimps and prawns), some differentiated (e.g. fish meat, mackerel). 
Table 2

Paola Conconi, Glenn Magerman, Afrola Plaku

Sensitivity to distance, imports of intermediate vs final goods, dropping raw materials

\begin{tabular}{|c|c|c|c|c|c|c|}
\hline & $(1)$ & $(2)$ & $(3)$ & $(4)$ & $(5)$ & $(6)$ \\
\hline Intermediate $_{k} \times \log \left(\right.$ Distance $\left._{i j}\right)$ & $\begin{array}{c}-0.031^{* * *} \\
(0.007)\end{array}$ & $\begin{array}{c}-0.024^{* * *} \\
(0.007)\end{array}$ & $\begin{array}{c}-0.036^{* * *} \\
(0.007)\end{array}$ & $\begin{array}{c}-0.030^{* * *} \\
(0.007)\end{array}$ & $\begin{array}{c}-0.032^{* * *} \\
(0.007)\end{array}$ & $\begin{array}{c}-0.025^{* * *} \\
(0.007)\end{array}$ \\
\hline Intermediate $_{k}$ & $\begin{array}{c}0.231^{* * *} \\
(0.055)\end{array}$ & $\begin{array}{c}0.188^{* * *} \\
(0.056)\end{array}$ & $\begin{array}{c}0.219^{* * *} \\
(0.054)\end{array}$ & $\begin{array}{c}0.172^{* *} \\
(0.055)\end{array}$ & $\begin{array}{c}0.243^{* * *} \\
(0.054)\end{array}$ & $\begin{array}{c}0.186^{* * *} \\
(0.055)\end{array}$ \\
\hline $\log \left(\right.$ Distance $\left._{i j}\right)$ & $\begin{array}{c}-0.363^{* * *} \\
(0.016)\end{array}$ & & $\begin{array}{c}-0.395^{* * *} \\
(0.016)\end{array}$ & & $\begin{array}{c}-0.453^{* * *} \\
(0.015)\end{array}$ & \\
\hline Contiguous $_{i j}$ & $\begin{array}{c}0.450^{* * *} \\
(0.052)\end{array}$ & & $\begin{array}{c}0.383^{* * *} \\
(0.046)\end{array}$ & & $\begin{array}{c}0.402^{* * *} \\
(0.044)\end{array}$ & \\
\hline Common Language $_{i j}$ & $\begin{array}{c}0.131^{* * * *} \\
(0.033)\end{array}$ & & $\begin{array}{c}0.115^{* * *} \\
(0.027)\end{array}$ & & $\begin{array}{c}0.149^{* * *} \\
(0.027)\end{array}$ & \\
\hline Colony $_{i j}$ & $\begin{array}{c}0.139 * * * \\
(0.035)\end{array}$ & & $\begin{array}{c}0.124^{* * *} \\
(0.034)\end{array}$ & & $\begin{array}{c}0.139 * * * \\
(0.036)\end{array}$ & \\
\hline $\mathrm{RTA}_{i j t}$ & $\begin{array}{c}0.240^{* * *} \\
(0.033)\end{array}$ & & $\begin{array}{c}0.164^{* * *} \\
(0.029)\end{array}$ & & $\begin{array}{c}0.125^{* * *} \\
(0.024)\end{array}$ & \\
\hline Exporter FE & Yes & Yes & Yes & Yes & Yes & Yes \\
\hline Importer FE & Yes & Yes & Yes & Yes & Yes & Yes \\
\hline Country-pair FE & No & Yes & No & Yes & No & Yes \\
\hline $\mathrm{HS} 2 \mathrm{FE}$ & Yes & Yes & Yes & Yes & Yes & Yes \\
\hline Year & 1998 & 1998 & 2004 & 2004 & 2010 & 2010 \\
\hline $\mathrm{N}$ & $4,517,900$ & $4,515,509$ & $5,226,087$ & $5,222,769$ & $5,749,171$ & $5,746,025$ \\
\hline $\mathrm{R}^{2}$ & 0.207 & 0.242 & 0.198 & 0.233 & 0.216 & 0.252 \\
\hline
\end{tabular}

The table reports the coefficients of OLS regressions. The dependent variable is the log of Imports $s_{i j k}$, the value of imports of HS6 product $k$ of country $i$ from country $j$. Standard errors in parenthesis clustered at the country-pair level. Significance levels: ${ }^{*} p<0.05,{ }^{* *} p<0.01,{ }^{* * *} p<0.001$.

The coefficient of the interaction term Intermediate $_{k} \times \log \left(\right.$ Distance $\left._{i j}\right)$ remains negative and significant, indicating that the higher sensitivity to distance of intermediate goods is not driven by the bulky nature of many inputs. In fact, excluding raw materials increases the gap between final and intermediate goods (the coefficient of Intermediate $_{k} \times \log \left(\right.$ Distance $\left._{i j}\right)$ is larger and more significant than in Table 1: Based on the specifications in columns 1, 3, and 5, the estimates imply that the distance elasticity is between $7.06 \%$ and $9.11 \%$ higher for intermediate goods relative to final goods.

Comparing Tables 1 and 2 suggests that, although most raw materials are intermediate inputs, these are generally less sensitive to distance, contrary to what suggested in previous studies (Miroudot et al., 2009). This could be because many goods classified as raw materials are natural resources (e.g. oil and minerals), which can only be sourced from a few countries in the world. Moreover, contracting frictions are less likely to be a serious problems in sourcing raw materials, since most of them are homogeneous intermediate goods, which do not need to be tailored to the specific needs of final good producers. 


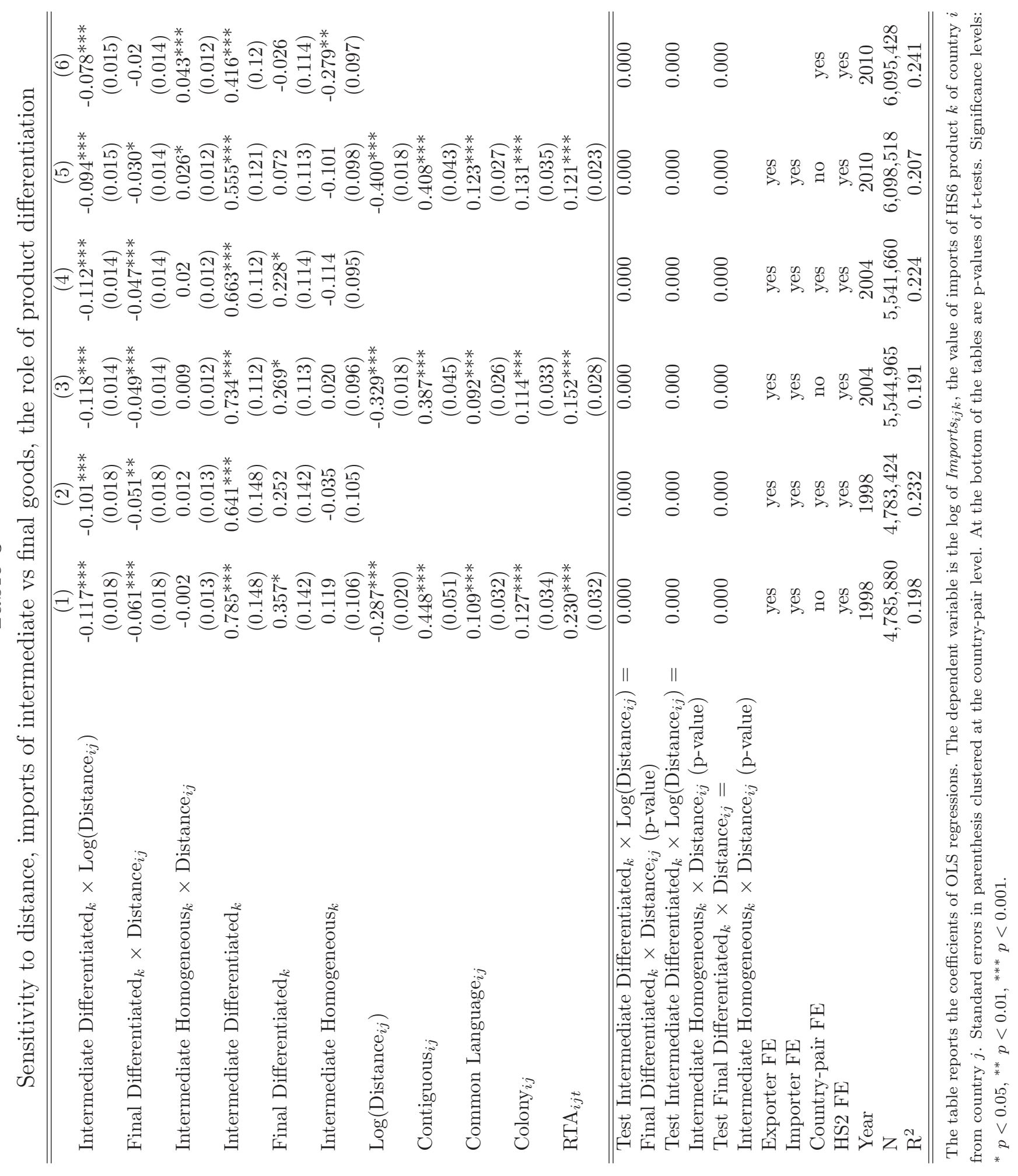


Finally, in Table 3 we report the results of estimating (2). As expected, differentiated intermediate goods are the most sensitive to distance: the coefficient of the interaction term Intermediate Differentiated $_{k} \times \log \left(\right.$ Distance $\left._{i j}\right)$ is negative and significantly larger in absolute terms than the coefficient of the other interaction terms (see the p-value of the tests reported at the bottom of the table). The results of Table 3 support the idea that contracting frictions along supply chains can lead final good producers to source inputs from nearby suppliers, particularly when the inputs need to be tailored to their specific needs.

In terms of magnitude, taking into account the role of product differentiation increases the gap in the sensitivity to distance of intermediate and final goods. For example, the estimates reported in column Table 3 imply that the distance elasticity is by $0.117 \%$ percentage points more negative for differentiated intermediate goods relative to homogeneous final goods, implying that the distance elasticity is $40.76 \%$ higher.

\subsection{Robustness Checks}

In the remaining of the section, we discuss the results of a series of additional estimations that we have carried out to verify the robustness of our results.

\section{Panel regressions}

In Tables 1-3, the gap in the sensitivity to distance between intermediate and final goods and the role of product differentiation are identified exploiting only cross-sectional variation in bilateral trade flows.

In what follows, we verify that the results continue to hold when we pool togethers all the years in our panel, including year fixed effects in (1) and (2) to account for macroeconomic conditions that may affect imports.

The results are reported in Tables 4-6. The negative and significant coefficient on the interaction between Intermediate $_{k}$ and $\log \left(\right.$ Distance $\left._{i j}\right)$ in Table 4 confirms that intermediate goods are more sensitive to distance than final goods. The results of Table 5 show that the gap between intermediate and final goods in their sensitivity to distance is larger and more significant if we exclude raw materials from the sample of products included in our analysis. Finally, Table 6 confirms that differentiated imports of intermediate goods are the most sensitive to distance, suggesting that contracting frictions play a key role in shaping sourcing decisions. 


\section{Table 4}

Sensitivity to distance, imports of intermediate vs final goods (panel regressions)

\begin{tabular}{|c|c|c|c|c|}
\hline & (1) & $(2)$ & $(3)$ & $(4)$ \\
\hline Intermediate $_{k} \times \log \left(\right.$ Distance $\left._{i j}\right)$ & $\begin{array}{c}-0.021^{* * *} \\
(0.006)\end{array}$ & $\begin{array}{c}-0.024^{* * *} \\
(0.006)\end{array}$ & $\begin{array}{c}-0.015^{*} \\
(0.006)\end{array}$ & $\begin{array}{c}-0.017^{* *} \\
(0.006)\end{array}$ \\
\hline Intermediate $_{k}$ & $\begin{array}{c}0.186^{* * *} \\
(0.049)\end{array}$ & $\begin{array}{c}0.153^{* *} \\
(0.049)\end{array}$ & $\begin{array}{l}0.123^{*} \\
(0.052)\end{array}$ & $\begin{array}{l}0.102^{*} \\
(0.051)\end{array}$ \\
\hline $\log (\text { Distance })_{i j}$ & $\begin{array}{c}-0.380^{* * *} \\
(0.013)\end{array}$ & $\begin{array}{c}-0.384^{* * *} \\
(0.014)\end{array}$ & & \\
\hline Contiguous $_{i j}$ & $\begin{array}{c}0.402^{* * *} \\
(0.044)\end{array}$ & $\begin{array}{c}0.402^{* * *} \\
(0.044)\end{array}$ & & \\
\hline Common Language $_{i j}$ & $\begin{array}{c}0.096^{* * *} \\
(0.025)\end{array}$ & $\begin{array}{c}0.103^{* * *} \\
(0.026)\end{array}$ & & \\
\hline Colony $_{i j}$ & $\begin{array}{c}0.106^{* * *} \\
(0.032)\end{array}$ & $\begin{array}{c}0.124^{* * *} \\
(0.032)\end{array}$ & & \\
\hline $\mathrm{RTA}_{i j t}$ & $\begin{array}{c}0.151^{* * *} \\
(0.022)\end{array}$ & $\begin{array}{c}0.153^{* * *} \\
(0.023)\end{array}$ & & \\
\hline Exporter x year FE & Yes & Yes & Yes & Yes \\
\hline Importer x year FE & Yes & Yes & Yes & Yes \\
\hline Year FE & Yes & No & No & No \\
\hline HS 2-digit x year FE & No & Yes & No & Yes \\
\hline Country pair x year FE & No & No & Yes & Yes \\
\hline $\mathrm{N}$ & $77,577,263$ & $77,496,670$ & $77,533,984$ & $77,453,869$ \\
\hline $\mathrm{R}^{2}$ & 0.171 & 0.202 & 0.205 & 0.236 \\
\hline
\end{tabular}

The table reports the coefficients of OLS regressions. The dependent variable is the log of Imports $_{k, i, j, t}$, the value of imports of HS6 product $k$ of country $i$ from country $j$ in year $t$. The panel covers the 19982011 period. Standard errors in parenthesis clustered at the country-pair level. Significance levels: * $p<0.05,{ }^{* *} p<0.01,{ }^{* * *} p<0.001$. 


\section{Table 5}

Sensitivity to distance, imports of intermediate vs final goods, dropping raw materials (panel regressions)

\begin{tabular}{|c|c|c|c|c|}
\hline & $(1)$ & $(2)$ & $(3)$ & $(4)$ \\
\hline Intermediate $_{k} \times \log \left(\right.$ Distance $\left._{i j}\right)$ & $\begin{array}{c}-0.028^{* * *} \\
(0.006)\end{array}$ & $\begin{array}{c}-0.031^{* * *} \\
(0.006)\end{array}$ & $\begin{array}{c}-0.023^{* * *} \\
(0.006)\end{array}$ & $\begin{array}{c}-0.024^{* * *} \\
(0.006)\end{array}$ \\
\hline Intermediate $_{k}$ & $\begin{array}{c}0.246^{* * *} \\
(0.05)\end{array}$ & $\begin{array}{c}0.204^{* * *} \\
(0.049)\end{array}$ & $\begin{array}{c}0.179^{* * *} \\
(0.052)\end{array}$ & $\begin{array}{c}0.154^{* *} \\
(0.051)\end{array}$ \\
\hline $\log \left(\right.$ Distance $\left._{i j}\right)$ & $\begin{array}{c}-0.400^{* * *} \\
(0.014)\end{array}$ & $\begin{array}{c}-0.406^{* * *} \\
(0.014)\end{array}$ & & \\
\hline Contiguous $_{i j}$ & $\begin{array}{c}0.406^{* * *} \\
(0.044)\end{array}$ & $\begin{array}{c}0.407^{* * *} \\
(0.045)\end{array}$ & & \\
\hline Common Language $_{i j}$ & $\begin{array}{c}0.120^{* * *} \\
(0.026)\end{array}$ & $\begin{array}{c}0.127^{* * *} \\
(0.026)\end{array}$ & & \\
\hline Colony $_{i j}$ & $\begin{array}{c}0.110^{* * *} \\
(0.033)\end{array}$ & $\begin{array}{c}0.130^{* * *} \\
(0.034)\end{array}$ & & \\
\hline $\mathrm{RTA}_{i j t}$ & $\begin{array}{c}0.157^{* * *} \\
(0.023)\end{array}$ & $\begin{array}{c}0.160 * * * \\
(0.023)\end{array}$ & & \\
\hline Exporter x year FE & Yes & Yes & Yes & Yes \\
\hline Importer x year FE & Yes & Yes & Yes & Yes \\
\hline Year FE & Yes & No & No & No \\
\hline HS 2-digit x year FE & No & Yes & No & Yes \\
\hline Country pair x year FE & No & No & Yes & Yes \\
\hline $\mathrm{N}$ & $73,173,076$ & $73,092,483$ & $73,129,720$ & $73,049,703$ \\
\hline $\mathrm{R}^{2}$ & 0.18 & 0.211 & 0.215 & 0.247 \\
\hline
\end{tabular}

The table reports the coefficients of OLS regressions. The dependent variable is the log of Imports $i j k t$, the value of imports of HS6 product $k$ of country $i$ from country $j$ in year $t$. The panel covers the 1998-2011 period. Standard errors in parenthesis clustered at the country-pair level. Significance levels: ${ }^{*} p<0.05,{ }^{* *} p<0.01,{ }^{* * *} p<0.001$. 


\section{Table 6}

Sensitivity to distance, imports of intermediate vs final goods, the role of product differentiation (panel regressions)

\begin{tabular}{|c|c|c|c|c|}
\hline & (1) & $(2)$ & $(3)$ & (4) \\
\hline Intermediate Differentiated $_{k} \times \log \left(\right.$ Distance $\left._{i j}\right)$ & $\begin{array}{c}-0.100^{* * *} \\
(0.014)\end{array}$ & $\begin{array}{c}-0.109^{* * *} \\
(0.014)\end{array}$ & $\begin{array}{c}-0.088^{* * *} \\
(0.014)\end{array}$ & $\begin{array}{c}-0.097^{* * *} \\
(0.014)\end{array}$ \\
\hline Final Differentiated $_{k} \times$ Distance $_{i j}$ & $\begin{array}{c}-0.048^{* * *} \\
(0.014)\end{array}$ & $\begin{array}{c}-0.048^{* * *} \\
(0.014)\end{array}$ & $\begin{array}{c}-0.040^{* *} \\
(0.014)\end{array}$ & $\begin{array}{c}-0.041^{* *} \\
(0.014)\end{array}$ \\
\hline Intermediate Homogeneous $_{k} \times$ Distance $_{i j}$ & $\begin{array}{c}0.004 \\
(0.011)\end{array}$ & $\begin{array}{c}0.013 \\
(0.011)\end{array}$ & $\begin{array}{c}0.016 \\
(0.011)\end{array}$ & $\begin{array}{l}0.026^{*} \\
(0.011)\end{array}$ \\
\hline Intermediate Differentiated $_{k}$ & $\begin{array}{c}0.624^{* * *} \\
(0.113)\end{array}$ & $\begin{array}{c}0.683^{* * *} \\
(0.113)\end{array}$ & $\begin{array}{c}0.584^{* * *} \\
(0.114)\end{array}$ & $\begin{array}{c}0.570^{* * *} \\
(0.113)\end{array}$ \\
\hline Final Differentiated $_{k}$ & $\begin{array}{c}0.217 \\
(0.113)\end{array}$ & $\begin{array}{l}0.248^{*} \\
(0.110)\end{array}$ & $\begin{array}{c}0.212 \\
(0.114)\end{array}$ & $\begin{array}{c}0.175 \\
(0.111)\end{array}$ \\
\hline Intermediate Homogeneous $_{k}$ & $\begin{array}{l}-0.037 \\
(0.091)\end{array}$ & $\begin{array}{r}-0.007 \\
(0.09)\end{array}$ & $\begin{array}{c}-0.146 \\
(0.09)\end{array}$ & $\begin{array}{l}-0.155 \\
(0.089)\end{array}$ \\
\hline $\log \left(\right.$ Distance $\left._{i j}\right)$ & $\begin{array}{c}-0.332^{* * *} \\
(0.016)\end{array}$ & $\begin{array}{c}-0.340^{* * *} \\
(0.017)\end{array}$ & & \\
\hline Contiguous $_{i j}$ & $\begin{array}{c}0.408^{* * *} \\
(0.044)\end{array}$ & $\begin{array}{c}0.409^{* * *} \\
(0.044)\end{array}$ & & \\
\hline Common Language $_{i j}$ & $\begin{array}{c}0.097^{* * *} \\
(0.025)\end{array}$ & $\begin{array}{c}0.103^{* * *} \\
(0.026)\end{array}$ & & \\
\hline Colony $_{i j}$ & $\begin{array}{c}0.103^{* *} \\
(0.032)\end{array}$ & $\begin{array}{c}0.121^{* * *} \\
(0.032)\end{array}$ & & \\
\hline $\mathrm{RTA}_{i j t}$ & $\begin{array}{c}0.150^{* * *} \\
(0.022)\end{array}$ & $\begin{array}{c}0.153^{* * *} \\
(0.023)\end{array}$ & & \\
\hline $\begin{array}{l}\text { Test Intermediate Differentiated }{ }_{k} \times \log \left(\text { Distance }_{i j}\right)= \\
\text { Final Differentiated }_{k} \times \text { Distance }_{i j}(\mathrm{p} \text {-value })\end{array}$ & $=0.000$ & 0.000 & 0.000 & 0.000 \\
\hline $\begin{array}{l}\text { Test Intermediate Differentiated }{ }_{k} \times \log \left(\text { Distance }_{i j}\right)= \\
\text { Intermediate Homogeneous }_{k} \times \text { Distance }_{i j}(\mathrm{p} \text {-value })\end{array}$ & 0.000 & 0.000 & 0.000 & 0.000 \\
\hline $\begin{array}{l}\text { Test Final Differentiated } \\
k \times \text { Distance }_{i j}= \\
\text { Intermediate Homogeneous }_{k} \times \text { Distance }_{i j}(\mathrm{p} \text {-value })\end{array}$ & 0.000 & 0.000 & 0.000 & 0.000 \\
\hline Exporter x year FE & Yes & Yes & Yes & Yes \\
\hline Importer x year FE & Yes & Yes & Yes & Yes \\
\hline Year FE & Yes & No & No & No \\
\hline HS 2-digit x year FE & No & Yes & No & Yes \\
\hline Country pair x year FE & No & No & Yes & Yes \\
\hline $\mathrm{N}$ & $77,496,671$ & $77,496,670$ & $77,453,870$ & $77,453,869$ \\
\hline $\mathrm{R}^{2}$ & 0.173 & 0.203 & 0.206 & 0.237 \\
\hline
\end{tabular}

The table reports the coefficients of OLS regressions. The dependent variable is the log of Imports $s_{i j k}$, the value of imports of HS6 product $k$ of country $i$ from country $j$. The panel covers the 1998-2011 period. Standard errors in parenthesis clustered at the country-pair level. At the bottom of the tables are p-values of t-tests. Significance levels: ${ }^{*} p<0.05,{ }^{* *} p<0.01,{ }^{* * *}$ $p<0.001$. 


\section{Alternative econometric model}

The results above are estimated using ordinary least squares (OLS) regressions. Santos Silva and Tenreyro (2006) point out that log-linearized models estimated with OLS can be misleading in the presence of heteroskedasticity. They proposed as a solution to use a Poisson pseudo-maximum likelihood (PPML) estimator. In Tables 7-9 we reproduce Tables 1-3 using the PPML estimator.

In Table 7 the coefficient is only negative and statistically significant in the first two columns. The estimates in column 1 indicate that the distance elasticity is $20.46 \%$ higher intermediate goods relative to final goods.

Table 8 confirms that excluding raw materials increases the gap between final and intermediate goods (the coefficient of Intermediate $_{k} \times \log \left(\right.$ Distance $\left._{i j}\right)$ is larger and more significant than in Table 1). Based on the specifications in columns 1, 3, and 5, the estimates imply that the distance elasticity is between $26.67 \%$ and $40.23 \%$ higher for intermediate goods relative to final goods.

Finally, the results of Table 9 confirm that differentiated intermediate goods are more sensitive to distance compared to homogeneous final goods (the coefficient of the interaction Intermediate Differentiated $_{k} \times \log \left(\right.$ Distance $\left._{i j}\right)$ is negative and significant), differentiated final goods (see p-value of the first test at the bottom of the table), and homogeneous intermediate goods (see p-value of the second test at the bottom of the table). These results suggest that contracting frictions along value chains may deter final good producers from sourcing intermediate inputs from distance suppliers, particularly when the inputs need to be adjusted to their needs.

In our analysis, we have focused on positive import values. Santos Silva and Tenreyro (2011) show that, besides being consistent in the presence of heteroskedasticity, the PPML method can also deal with zero values of the dependent variable. However, in their Monte Carlo simulations, they allow zeros to account for between 62 and 83 percent of the observations. In our product-level regressions, zeros would instead account for almost the totality of the observations in our sample. ${ }^{6}$

\footnotetext{
${ }^{6}$ For example, if we included zeros in column 1 of Table 7 , they would account for almost $98 \%$ of the sample (the number of observations would increase from 4,785,880 to 222,746,370). We have nevertheless tried to reproduce Tables 7-9, including zeros in the dependent variable. The results confirm that intermediate goods are more sensitive to distance than final goods, particularly when eliminating raw materials. However, the role of product differentiation is less clearcut (intermediate goods are more sensitive to distance than only two of the three other categories of products).
} 


\section{Table 7}

Sensitivity to distance, imports of intermediate vs final goods (PPML)

\begin{tabular}{|c|c|c|c|c|c|c|}
\hline Intermediate $_{k} \times \log \left(\right.$ Distance $\left._{i j}\right)$ & $\begin{array}{c}-0.053^{*} \\
(0.027)\end{array}$ & $\begin{array}{c}-0.064^{*} \\
(0.027)\end{array}$ & $\begin{array}{l}-0.010 \\
(0.047)\end{array}$ & $\begin{array}{l}-0.031 \\
(0.048)\end{array}$ & $\begin{array}{c}0.013 \\
(0.052)\end{array}$ & $\begin{array}{l}-0.006 \\
(0.054)\end{array}$ \\
\hline Intermediate $_{k}$ & $\begin{array}{c}0.530^{*} \\
(0.215)\end{array}$ & $\begin{array}{c}0.619 * * \\
(0.216)\end{array}$ & $\begin{array}{l}-0.039 \\
(0.361)\end{array}$ & $\begin{array}{c}0.122 \\
(0.371)\end{array}$ & $\begin{array}{l}-0.022 \\
(0.404)\end{array}$ & $\begin{array}{c}0.136 \\
(0.415)\end{array}$ \\
\hline $\log \left(\right.$ Distance $\left._{i j}\right)$ & $\begin{array}{c}-0.259 * * * \\
(0.035)\end{array}$ & & $\begin{array}{c}-0.342^{* * *} \\
(0.036)\end{array}$ & & $\begin{array}{c}-0.367^{* * *} \\
(0.041)\end{array}$ & \\
\hline Contiguous $_{i j}$ & $\begin{array}{c}0.507^{* * *} \\
(0.059)\end{array}$ & & $\begin{array}{c}0.378^{* * *} \\
(0.058)\end{array}$ & & $\begin{array}{c}0.386^{* * *} \\
(0.071)\end{array}$ & \\
\hline Common Language $_{i j}$ & $\begin{array}{c}0.083 \\
(0.057)\end{array}$ & & $\begin{array}{l}-0.049 \\
(0.069)\end{array}$ & & $\begin{array}{l}-0.092 \\
(0.085)\end{array}$ & \\
\hline Colony $_{i j}$ & $\begin{array}{l}-0.010 \\
(0.068)\end{array}$ & & $\begin{array}{l}-0.032 \\
(0.073)\end{array}$ & & $\begin{array}{c}0.016 \\
(0.077)\end{array}$ & \\
\hline $\mathrm{RTA}_{i j t}$ & $\begin{array}{c}0.614^{* * * *} \\
(0.063)\end{array}$ & & $\begin{array}{c}0.471^{* * * *} \\
(0.060)\end{array}$ & & $\begin{array}{c}0.282^{* * * *} \\
(0.062) \\
\end{array}$ & \\
\hline Exporter FE & Yes & Yes & Yes & Yes & Yes & Yes \\
\hline Importer FE & Yes & Yes & Yes & Yes & Yes & Yes \\
\hline Country-pair FE & No & Yes & No & Yes & No & Yes \\
\hline HS2 FE & Yes & Yes & Yes & Yes & Yes & Yes \\
\hline Year & 1998 & 1998 & 2004 & 2004 & 2010 & 2010 \\
\hline $\mathrm{N}$ & $4,785,880$ & $4,783,424$ & $5,544,965$ & $5,541,660$ & $6,098,518$ & $6,095,428$ \\
\hline Pseudo $\mathrm{R}^{2}$ & 0.312 & 0.342 & 0.326 & 0.364 & 0.348 & 0.392 \\
\hline
\end{tabular}

The table reports the coefficients of PPML regressions. The dependent variable is the log of Imports $s_{i j k}$, the value of imports of HS6 product $k$ of country $i$ from country $j$. Standard errors in parenthesis clustered at the country-pair level. Significance levels: ${ }^{*} p<0.05,{ }^{* *} p<0.01,{ }^{* * *} p<0.001$. 
Table 8

Sensitivity to distance, imports of intermediate vs final goods, dropping raw materials (PPML)

\begin{tabular}{|c|c|c|c|c|c|c|}
\hline Intermediate $_{k} \times \log \left(\right.$ Distance $\left._{i j}\right)$ & $\begin{array}{c}-0.107 * * * \\
(0.026)\end{array}$ & $\begin{array}{c}-0.114^{* * *} \\
(0.026)\end{array}$ & $\begin{array}{c}-0.119^{* *} \\
(0.040)\end{array}$ & $\begin{array}{c}-0.127^{* *} \\
(0.042)\end{array}$ & $\begin{array}{c}-0.108^{*} \\
(0.045)\end{array}$ & $\begin{array}{c}-0.117^{*} \\
(0.046)\end{array}$ \\
\hline Intermediate $_{k}$ & $\begin{array}{c}0.967^{* * *} \\
(0.206)\end{array}$ & $\begin{array}{c}1.021^{* * *} \\
(0.210)\end{array}$ & $\begin{array}{c}0.831^{* *} \\
(0.307)\end{array}$ & $\begin{array}{c}0.894^{* *} \\
(0.319)\end{array}$ & $\begin{array}{c}0.957^{* *} \\
(0.343)\end{array}$ & $\begin{array}{c}1.028^{* *} \\
(0.355)\end{array}$ \\
\hline $\log \left(\right.$ Distance $\left._{i j}\right)$ & $\begin{array}{c}-0.266^{* * *} \\
(0.035)\end{array}$ & & $\begin{array}{c}-0.368^{* * *} \\
(0.033)\end{array}$ & & $\begin{array}{c}-0.405^{* * *} \\
(0.034)\end{array}$ & \\
\hline Contiguous $_{i j}$ & $\begin{array}{c}0.494^{* * *} \\
(0.061)\end{array}$ & & $\begin{array}{c}0.350^{* * *} \\
(0.061)\end{array}$ & & $\begin{array}{c}0.322^{* * *} \\
(0.061)\end{array}$ & \\
\hline Common Language $_{i j}$ & $\begin{array}{c}0.118^{*} \\
(0.057)\end{array}$ & & $\begin{array}{l}-0.011 \\
(0.073)\end{array}$ & & $\begin{array}{c}0.006 \\
(0.076)\end{array}$ & \\
\hline Colony $_{i j}$ & $\begin{array}{c}0.029 \\
(0.067)\end{array}$ & & $\begin{array}{l}-0.004 \\
(0.078)\end{array}$ & & $\begin{array}{c}0.084 \\
(0.079)\end{array}$ & \\
\hline $\mathrm{RTA}_{i j t}$ & $\begin{array}{c}0.641^{* * *} \\
(0.065)\end{array}$ & & $\begin{array}{c}0.451^{* * * *} \\
(0.061)\end{array}$ & & $\begin{array}{c}0.263^{* * *} \\
(0.051)\end{array}$ & \\
\hline Exporter FE & Yes & Yes & Yes & Yes & Yes & Yes \\
\hline Importer FE & Yes & Yes & Yes & Yes & Yes & Yes \\
\hline Country-pair FE & No & Yes & No & Yes & No & Yes \\
\hline HS2 FE & Yes & Yes & Yes & Yes & Yes & Yes \\
\hline Year & 1998 & 1998 & 2004 & 2004 & 2010 & 2010 \\
\hline $\mathrm{N}$ & $4,517,900$ & $4,515,509$ & $5,226,087$ & $5,222,769$ & $5,749,171$ & $5,746,025$ \\
\hline Pseudo $\mathrm{R}^{2}$ & 0.319 & 0.346 & 0.303 & 0.337 & 0.317 & 0.355 \\
\hline
\end{tabular}

The table reports the coefficients of PPML regressions. The dependent variable is the log of Imports $i_{i j k}$, the value of imports of HS6 product $k$ of country $i$ from country $j$. Standard errors in parenthesis clustered at the country-pair level. Significance levels: ${ }^{*} p<0.05,{ }^{* *} p<0.01,{ }^{* * *} p<0.001$ 


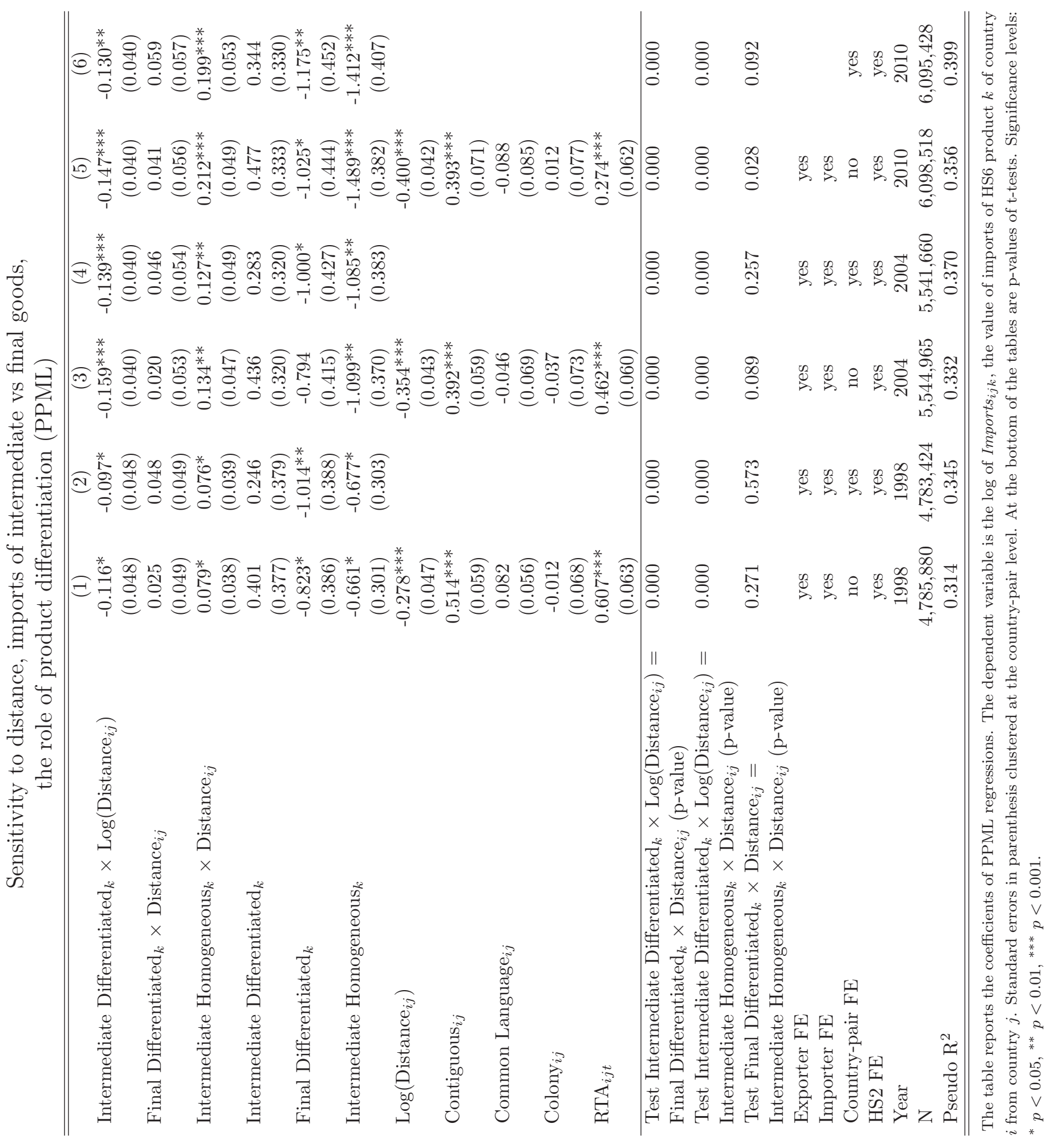




\section{Conclusions}

The last few decades have seen a dramatic reduction in trade costs (transport costs, communication costs, and tariff barriers). These changes have fostered the fragmentation of production processes across countries, leading to the emergence of GVCs and a rise of trade in intermediate goods. Surprisingly, during this period, trade flows have not become less sensitive to distance.

In this paper, we show that the emergence of GVCs can help to explain the distance puzzle. We show that intermediate goods - and particularly differentiated inputs - are more sensitive to distance than final goods. These results are robust to including different sets of fixed effects and controls, exploiting cross-sectional and time series variation in trade flows, and using alternative econometric methodologies.

Our analysis suggest that, although fragmenting production across firms and countries has become easier, contractual frictions remain a significant obstacle to the globalization of supply chains. Sourcing inputs from nearby countries can allow producers to better coordinate with suppliers and monitor their production. Using more distant suppliers can give rise to problems and delays in the production of key inputs, which can disrupt the entire supply chain.

Our results are based on a panel dataset of bilateral trade flows, covering around 5,000 products and a large number of countries over the 1998-2011 period. An important avenue of future research is to examine how distance and other bilateral determinants of trade flows (e.g. common language, membership in trade agreements) shape the sourcing decisions of individual firms.

\section{References}

Alfaro, Laura, Pol Antràs, Paola Conconi, and Davin Chor (2015), "Internalizing Global Value Chains: A Firm-Level Analysis," Journal of Political Economy 127, 508-559.

Amiti, M., and J. Konings (2007). "Trade Liberalization, Intermediate Inputs, and Productivity: Evidence from Indonesia," American Economic Review 97, 1611-1638.

Anderson, J. E., and Y. Yotov (2010). "The Changing Incidence of Geography," American Economic Review 100, 2157-2186.

Antràs, P., and D. Chor (2013). "Organizing the Global Value Chain," Econometrica 81, 2127-2204. 
Antràs, Pol (2016), Global Production: Firms, Contracts and Trade Structure, Princeton University Press.

Antràs, P., T. C. Fort, and F. Tintelnot (2017). "The Margins of Global Sourcing: Theory and Evidence from US Firms," American Economic Review 107, 2514-64.

Baldwin, R. (2013). "Global Supply Chains: Why They Emerged, Why They Matter, and Where They Are Going," in D. K. Elms and P. Low (eds.), Global Value Chains in a Changing World, World Trade Organization.

Baldwin, R., and D. Taglioni (2011). "Gravity Chains: Estimating Bilateral Trade Flows When Parts And Components Trade Is Important," NBER Working Paper No. 16672.

Bergstrand, J., and P. Egger (2010). "A General Equilibrium Theory for Estimating Gravity Equations of Bilateral FDI, Final Goods Trade and Intermediate Goods Trade," in S. Brakman, and P. Van Bergeijk (eds), The Gravity Model in International Trade: Advances and Applications. Cambridge University Press, New York.

Bernard, A. B., J. B. Jensen, S. J. Redding, and P. K. Schott (2007). "Firms in International Trade," Journal of Economic Perspectives 21, 105-130.

Blaum, J., C. Lelarge, and M. Peters (2018). "The Gains from Input Trade with Heterogeneous Importers," American Economic Journal: Macroeconomics 10, 77-127.

Cairncross, F. (1997). The Death of Distance: How the Communications Revolution will Change our Lives .Orion Business Books, London, U.K.

Combes, P-P., T. Mayer, and J.?F. Thisse (2008). Economic Geography: The Integration of Regions and Nations. Princeton University Press, Princeton.

Conconi, P., M. Garca-Santana, L. Puccio, and R. Venturini (2018a). "From Final Goods to Inputs: The Protectionist Effect of Rules of Origin," American Economic Review 108, 2335-2365.

Disdier, A.-C., and K. Head (2008). "The Puzzling Persistence of the Distance Effect on Bilateral Trade," Review of Economics and Statistics 90, 37-48.

Glaeser, E.L., and J.E. Kohlhase (2004). "Cities, Regions and the Decline of Transport Costs," Papers in Regional Science 83, 197-228.

Goldberg, P. K., A. K. Khandelwal, N. Pavcnik, and P. Topalova (2010). "Imported Intermediate Inputs and Domestic Product Growth: Evidence from India," Quarterly Journal of Economics 125, 1727-1767. 
Imbs, J., and I. Mejean (2017). "Trade Elasticities," Review of International Economics 25, 383-402.

Johnson, R. C. and G. Noguera (2012). "Accounting for Intermediates: Production Sharing and Trade in Value Added," Journal of International Economics 86, 224-236.

Leamer, E.E., and J. Levinsohn (1995). "International Trade Theory: The Evidence," in G. Grossman and K. Rogoff (eds.), Handbook of International Economics Volume 3. North-Holland, Amsterdam.

Miroudot, S., R. Lanz and A. Ragoussis (2009). "Trade in Intermediate Goods and Services," OECD Trade Policy Papers No. 93.

Nunn, N. (2007), "Relationship-Specificity, Incomplete Contracts and the Pattern of Trade," Quarterly Journal of Economics 122, 569-600.

Rauch, J. E. (1999), "Networks versus Markets in International Trade," Journal of International Economics 48, 7-35.

Santos Silva, J., and S. Tenreyro (2006). "The Log of Gravity," Review of Economics and Statistics 88, 641-658.

Santos Silva, J., and S. Tenreyro (2011). "Further Simulation Evidence on the Performance of the Poisson-PML Estimator," Economics Letters 112, 220-222. 
Table A 1

Descriptive statistics of main variables

\begin{tabular}{lcccc}
\hline \hline Variable & $\mathrm{N}$ & Mean & Median & Standard deviation \\
\hline Imports $_{i j k t}$ & $77,577,263$ & $1,424,317$ & 27,329 & $55.3 \times 10^{6}$ \\
Intermediate $_{k}$ & $77,577,263$ & 0.529 & 1 & 0.500 \\
Differentiated $_{k}$ & $77,577,263$ & 0.760 & 1 & 0.427 \\
Distance $_{i j}$ & $77,577,263$ & 5,449 & 1,542 & 4,432 \\
Contiguous $_{i j}$ & $77,577,263$ & 0.097 & 0 & 0.295 \\
Common Language $_{i j}$ & $77,577,263$ & 0.175 & 0 & 0.380 \\
Colony $_{i j}$ & $77,577,263$ & 0.076 & 0 & 0.265 \\
RTA $_{i j t}$ & $77,577,263$ & 0.357 & 0 & 0.479 \\
\hline \hline
\end{tabular}

The table provide descriptive statistics for the main variables used in our empirical analysis, for the period 1998-2011 period. See Section 3 for the definition and sources of all variables. 
Author contacts:

Paola Conconi (corresponding author)

Université Libre de Bruxelles (ECARES), CEPR and CESifo

Email: Paola Conconi <pconconi@ulb.ac.be>

\section{Glenn Magerman}

Université Libre de Bruxelles (ECARES) and National Bank of Belgium

\section{Afrola Plaku}

Université Libre de Bruxelles (ECARES) 